\title{
Solubility limit and precipitate formation in Al-doped 4H-SiC epitaxial material
}

\author{
M. K. Linnarsson, ${ }^{\text {a) }}$ M. S. Janson, U. Zimmermann, and B. G. Svensson ${ }^{\text {b) }}$ \\ Royal Institute of Technology, Solid State Electronics, P. O. Box E229, SE-164 40 Kista-Stockholm, Sweden \\ P. O. Å. Persson and L. Hultman \\ Linköping University, Department of Physics and Measurement Technology, SE-581 83 Linköping, Sweden \\ J. Wong-Leung \\ Australian National University, Department of Electronics Materials Engineering, Research School of \\ Physical Sciences and Engineering, Canberra ACT 0200, Australia
}

S. Karlsson and A. Schöner

ACREO AB, P. O. Box E236, SE-164 40 Kista-Stockholm, Sweden

$\mathrm{H}$. Bleichner

ABB Corporate Research, P. O. Box E215, SE-164 40 Kista-Stockholm, Sweden

E. Olsson

The Angström Laboratory, Analytical Material Physics, SE-751 21 Uppsala, Sweden

(Received 21 February 2001; accepted for publication 23 July 2001)

\begin{abstract}
Heavily Al-doped $4 \mathrm{H}-\mathrm{SiC}$ structures have been prepared by vapor phase epitaxy. Subsequent anneals have been carried out in an Ar atmosphere in a rf-heated furnace between $1500{ }^{\circ} \mathrm{C}$ and $2000{ }^{\circ} \mathrm{C}$ for 0.5 to $3 \mathrm{~h}$. Secondary ion mass spectrometry has been utilized to obtain $\mathrm{Al}$ concentration versus depth as well as lateral distributions (ion images). Transmission electron microscopy (TEM) has been employed to study the crystallinity and determine phase composition after heat treatment. A solubility limit of $\sim 2 \times 10^{20} \mathrm{Al} / \mathrm{cm}^{3}\left(1900^{\circ} \mathrm{C}\right)$ is extracted. Three-dimensional ion images show that the $\mathrm{Al}$ distribution does not remain homogeneous in layers heat treated at $1700^{\circ} \mathrm{C}$ or above when the $\mathrm{Al}$ concentration exceeds $2 \times 10^{20} \mathrm{~cm}^{-3}$. Al-containing precipitates are identified by energy-filtered TEM. (C) 2001 American Institute of Physics. [DOI: 10.1063/1.1402160]
\end{abstract}

High quality ohmic contacts require heavily doped $\mathrm{SiC}$ where doping levels close to the solubility limit are appreciated. If the solubility limit is exceeded, precipitates may form and the thermal stability and performance of SiC devices can be affected. For $p$-type ohmic contacts, heavily aluminum doped $\mathrm{SiC}$ is of prime interest. These highly doped layers can be prepared by ion implantation or during epitaxial growth taking advantage of site competition. ${ }^{1}$ Dopant incorporation during epitaxial growth is kineticcontrolled and solubility limits may be exceeded. The kinetic nature of $\mathrm{Al}$ incorporation can be elucidated by the anisotropy in "solubility limits" of $7 \times 10^{20}[(0001)$, silicon face $]$ and $9 \times 10^{19}\left[(000 \overline{1})\right.$ carbon face $\mathrm{Al} / \mathrm{cm}^{3}$ in sublimation grown $6 \mathrm{H}-\mathrm{SiC}$ reported by Vodakov et al. ${ }^{2}$ For postgrowth heat treatments, thermodynamic considerations have to be made. The thermal stability of heavily Al doped contact layers can be predicted from the ternary phase diagram $\mathrm{Al}-\mathrm{Si}-\mathrm{C} .^{3-6}$ The three binary subsystems are well known with two intermediate phases, $\mathrm{Al}_{4} \mathrm{C}_{3}$ and $\mathrm{SiC}$. Three ternary phases, $\mathrm{Al}_{8} \mathrm{SiC}_{7}, \mathrm{Al}_{4} \mathrm{SiC}_{4}$, and $\mathrm{Al}_{4} \mathrm{Si}_{2} \mathrm{C}_{5}$ have been reported ${ }^{3-7}$ but the stability of $\mathrm{Al}_{4} \mathrm{Si}_{2} \mathrm{C}_{5}$ is questioned. ${ }^{3}$ The chemical interaction between pure aluminum and $\mathrm{SiC}$ is well documented over a broad temperature range (room tempera-

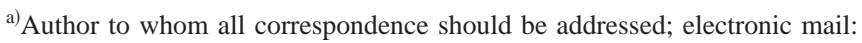
marga@ele.kth.se

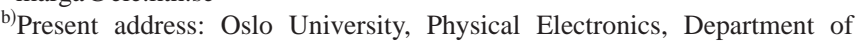
Physics, P. B. 1048 Blindern, N-0316 Oslo, Norway.
}

ture up to $\left.1600^{\circ} \mathrm{C}\right),{ }^{4,5}$ but unfortunately, the $\mathrm{SiC}$ rich side, which is the area of interest for highly doped $\mathrm{SiC}$ layers, is not known in detail.

In this letter, we report on the solubility limit and precipitate formation in heavily $\mathrm{Al}$ doped epitaxially grown $p$-type $4 \mathrm{H}-\mathrm{SiC}$. After heat treatment, precipitate formation is observed in layers with $\mathrm{Al}$ concentration exceeding 2 $\times 10^{20} \mathrm{~cm}^{-3}$. Al concentration versus depth profiles as well as lateral distributions (ion images) have been measured by secondary ion mass spectrometry (SIMS). Transmission electron microscopy (TEM) has been utilized to investigate the crystal structure and determine phase compositions in the heavily doped $\mathrm{SiC}$.

$\mathrm{Al}$ doped $4 \mathrm{H}-\mathrm{SiC}$ structures were prepared by vapor phase epitaxy at $1500{ }^{\circ} \mathrm{C}$. The structure consists of five $\mathrm{Al}$ doped layers in the concentration range $2 \times 10^{19}$ to 3 $\times 10^{20} \mathrm{~cm}^{-3}$ separated by undoped material. A small variation in the $\mathrm{Al}$ concentration over the wafer is present. Subsequent heat treatments were performed in an Ar atmosphere in a rf-heated furnace according to a time and temperature schedule that varied from 0.5 to $3 \mathrm{~h}$ in duration and $1500^{\circ} \mathrm{C}$ to $2000^{\circ} \mathrm{C}$. The aluminum depth distribution as well as lateral distribution (ion images) were measured by SIMS using a Cameca IMS $4 \mathrm{f}$ microanalyzer. A primary sputtering beam of $8.2 \mathrm{keV}^{32}\left(\mathrm{O}_{2}\right)^{+}$was applied and secondary ${ }^{27} \mathrm{Al}^{+}$ions were detected. For depth profiling, the primary beam was rastered over an area of $200 \times 200 \mu \mathrm{m}^{2}$ and the $\mathrm{Al}$ signal was recorded from the central part of this area $(\sim 60 \mu \mathrm{m}$ in di- 


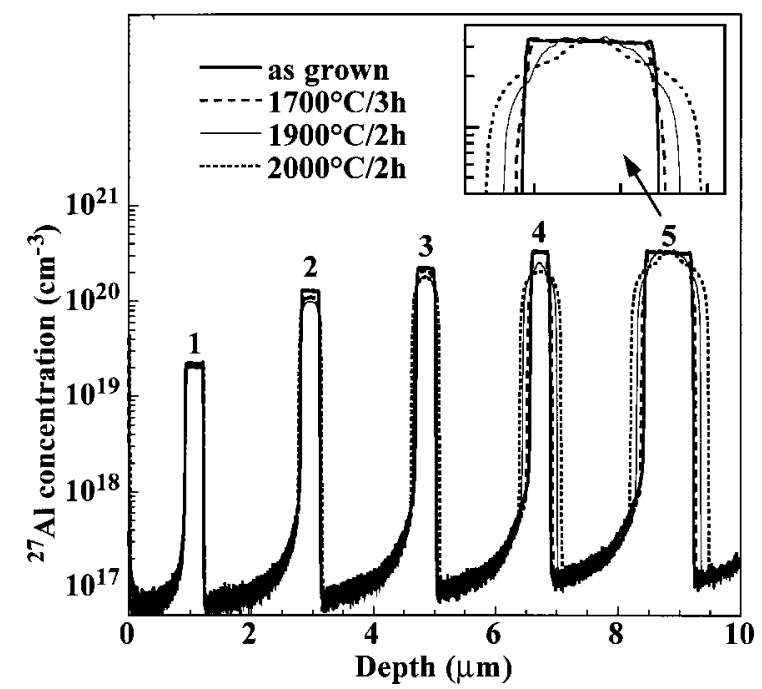

FIG. 1. SIMS profiles of the aluminum concentration versus depth for $4 \mathrm{H}-$ $\mathrm{SiC}$ samples are shown. Four samples are analyzed, one as grown and three annealed at $1700^{\circ} \mathrm{C}, 1900^{\circ} \mathrm{C}$, and $2000^{\circ} \mathrm{C}$ for $3 \mathrm{~h}, 2 \mathrm{~h}$, and $2 \mathrm{~h}$, respectively. $\mathrm{Al}$ diffusion decreases when the $\mathrm{Al}$ concentration decreases and no broadening of layer 1 is observed.

ameter). During ion image acquisition, a stack of 360 images was recorded. The primary beam (diameter $\leqslant 1 \mu \mathrm{m}$ ) was rastered over an area of $25 \times 25 \mu \mathrm{m}^{2}$ and the time of collecting data corresponds to a depth of $24 \AA$ per image (i.e., the thickness of the image). High resolution transmission electron microscopy (HRTEM) was performed in a Philips CM20UT operated at $200 \mathrm{kV}$ and a TECHNAI F30 ST FEGTEM operated at $300 \mathrm{kV}$ was employed for energy-filtered TEM (EFTEM).

A strong concentration dependence is observed for the $\mathrm{Al}$ diffusion. For instance, Fig. 1 shows four SIMS spectra of the ${ }^{27} \mathrm{Al}$ depth distribution in an as-grown sample and after heat treatment at $1700^{\circ} \mathrm{C}, 1900^{\circ} \mathrm{C}$, and $2000^{\circ} \mathrm{C}$ for $3 \mathrm{~h}, 2 \mathrm{~h}$, and $2 \mathrm{~h}$, respectively. The as grown $\mathrm{Al}$ concentration in layer 1 to 5 is $0.2,1,2,3$, and 3 multiplied by $10^{20} \mathrm{~cm}^{-3}$, respectively. Al diffusion is detected in four of the five of the $\mathrm{Al}$ structures. No diffusion is observed at the lowest level (layer 1 ), but when the concentration increases, a remarkable increase in diffusion is revealed. The outdiffusion is symmetric and the diffusion fronts are very abrupt with a shape diverging from a pure Fickian diffusion with no concentration dependence of the diffusion coefficient. In layer 5 , the outdiffusion starts at a level of about $2 \times 10^{20} \mathrm{~cm}^{-3}$ while a region with higher concentration, i.e., the as grown concentration, remains in the center of the layer. If the annealing time increases, the region with the as-grown concentration is reduced and at long enough times, the concentration in the center of the fifth layer decreases (not shown in Fig. 1). The same type of diffusion curves is obtained after heat treatment at $1700^{\circ} \mathrm{C}$ to $2000^{\circ} \mathrm{C}$ for 0.5 to $3 \mathrm{~h}$. As long as the as-grown concentration remains in the center of layer 5 , the level of outdiffusion does not change with time. No diffusion is detected at $1500^{\circ} \mathrm{C}$ for $0.5 \mathrm{~h}$. Diffusion curves of this kind indicate that the solubility limit has been exceeded and that precipitates may form. The level of outdiffusion can be interpreted as a solubility limit, in this case $\sim 2$ $\times 10^{20} \mathrm{Al} / \mathrm{cm}^{3}\left(1900^{\circ} \mathrm{C}\right)$. If the temperature is increased from $1700^{\circ} \mathrm{C}$ to $2000^{\circ} \mathrm{C}$, the level of outdiffusion is increased by $\sim 30 \%$. tical to the depth profile shown in Fig. 1 where the volume of
creased by $\sim 30 \%$.
Downloaded 10 Oct 2007 to 150.203 .178 .60 . Redistribution subject to AlP license or copyright, see http://apl.aip.org/apl/copyright.jsp

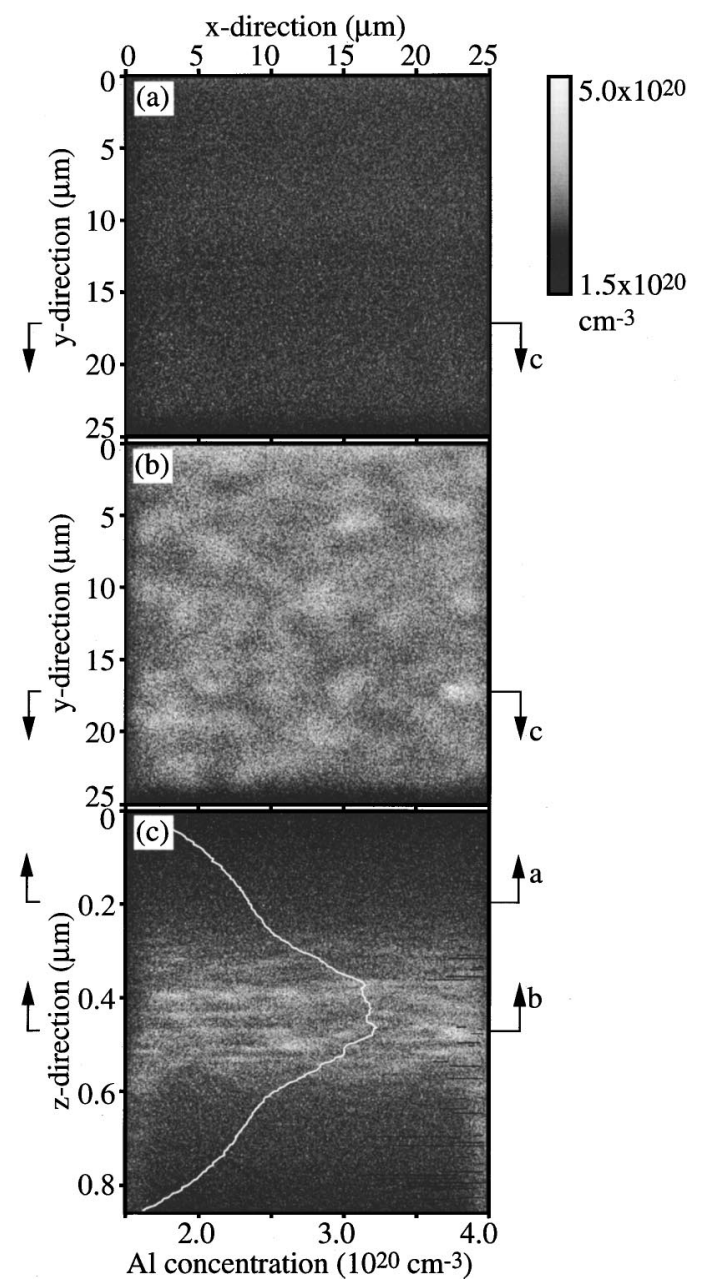

FIG. 2. Ion image of the Al distribution obtained by SIMS is shown. The data is recorded in layer 5 of the sample heat treated at $2000{ }^{\circ} \mathrm{C}$ for $2 \mathrm{~h}$ shown in Fig. 1. A higher $\mathrm{Al}$ concentration is displayed as a brighter region. In the ion images (a) and (b) the Al distribution in a $x y$ plane parallel to the surface is shown for the middle of the layer and at the outdiffused shoulder, respectively. In (c), data from $360 x y$ images have been used to construct the $x z$ image. On top of the $x z$ image, the average $\mathrm{Al}$ concentration in each $x y$ image is plotted versus depth, the $z$ direction. In this case, a linear concentration scale is used.

After heat treatment at $1700^{\circ} \mathrm{C}$ or above, the lateral $\mathrm{Al}$ distribution does not remain homogeneous in layers with $\mathrm{Al}$ concentrations above $2 \times 10^{20} \mathrm{~cm}^{-3}$. Figure 2 shows SIMS images of a layer with $3 \times 10^{20} \mathrm{Al} / \mathrm{cm}^{-3}$ after heat treatment at $2000^{\circ} \mathrm{C}$ for $2 \mathrm{~h}$. A higher $\mathrm{Al}$ concentration is displayed as a brighter region in the images. The $\mathrm{Al}$ distribution is shown in two $x y$ planes parallel and in one $x z$ plane perpendicular to the sample surface $\left[7^{\circ}\right.$ off from (0001) plane]. Data from $360 x y$ images have been used to construct the $x z$ image. The lateral resolution in the $x y$ plane is given by the diameter of the sputtering beam, typically $\leqslant 1 \mu \mathrm{m}$. Frequent small structures, homogeneously distributed, may therefore not be resolved. In the $z$ direction, the resolution is limited by the thickness of the ion images and/or the cascade mixing (as determined from $\mathrm{Al} \delta$ layers), $24 \AA$ and $25 \AA$, respectively. In Fig. 2(c), the smallest resolvable structure in the $z$ direction has the extension of three ion images. Furthermore, the Al concentration, in linear scale, versus depth is included in the $x z$ image. The depth profile has been extracted as an average of the $\mathrm{Al}$ concentration in each $x y$ plane. This profile is iden- 


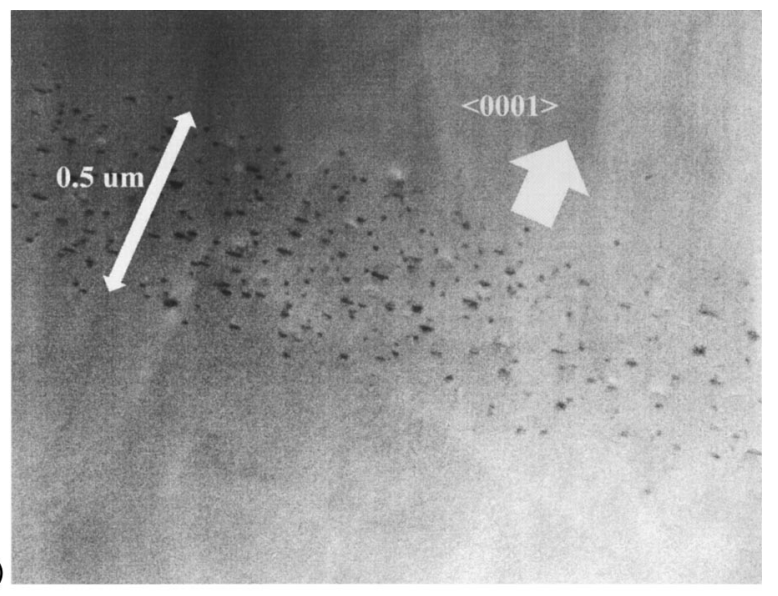

(a)

$$
\text { (b) }
$$

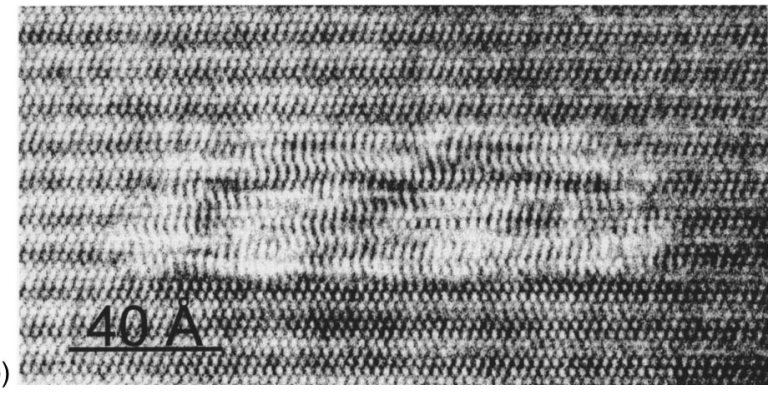

FIG. 3. (a) Cross-sectional TEM image of heavily Al doped $4 \mathrm{H}-\mathrm{SiC}$ after anneal at $2000{ }^{\circ} \mathrm{C}$ for 30 mins is shown. A track of defects is observed in the middle of the fifth Al layer (see Fig. 1). A preferential orientation of defects along the $c$ axis is observed. (b) Cross sectional HRTEM of one of the

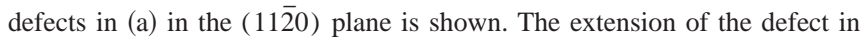
the $\langle 0001\rangle$ direction coincides with for four unit cells of $4 \mathrm{H}-\mathrm{SiC}$.

each data point was three times larger compared to the one used in the ion imaging.

HRTEM has been used to further investigate the crystal structure and in particular to determine if precipitates are formed. Cross sections were prepared from two samples, one as grown and one heat treated at $2000^{\circ} \mathrm{C}$ for $30 \mathrm{~min}$. No precipitates were detected in the as-grown sample and the lattice seems to be unaffected except for layer 5, where the lattice shows some evidence of stress. After heat treatment at $2000^{\circ} \mathrm{C}$, no disorder was revealed in the layers 1 to 4 while a $0.5 \mu \mathrm{m}$ broad track of defects was observed in layer 5 [Fig. $3(\mathrm{a})$. These defects are three dimensional, with a preferential orientation along the $c$ axes in SiC. In Fig. 3(b), a HRTEM image of one defect is displayed. The surrounding $\mathrm{SiC}$ lattice is not markedly influenced. A typical thickness of the structure is $40 \AA$ and the extension in the $c$ plane is in the range of 30 to $300 \AA$. If $1 \times 10^{20} \mathrm{Al}$ atoms mixed with $5 \times 10^{22} \mathrm{Si}$ atoms form $\mathrm{Al}$ containing precipitates with a size of 300 $\times 300 \AA^{2}$, there will be about two preciptates $/ \mu \mathrm{m}^{2}$ in the (0001) plane. This is close to the detection limit for SIMS ion images in the $x y$ plane, since at higher precipitate densities, homogeneously distributed, the $\mathrm{Al}$ intensity will average out. The extension of the precipitates in the $z$ direction in a SIMS $x z$ image is similar to that deduced from HRTEM [Figs. 2 and 3(b)].

These results obtained by SIMS and HRTEM are further substantiated by EFTEM revealing that the precipitates are an $\mathrm{Al}$ containing phase. EFTEM also suggests a reduction of the $\mathrm{Si}$ concentration of the precipitates relative to the matrix. According to the ternary $\mathrm{Al}-\mathrm{Si}-\mathrm{C}$ phase diagram ${ }^{3}$ when the Downloaded 10 Oct 2007 to 150.203 .178 .60 . Redistribution subject solubility limit of $\mathrm{Al}$ in $\mathrm{SiC}$ is exceeded $\mathrm{Al}_{4} \mathrm{SiC}_{4}$ will most probably form. $\mathrm{Al}_{4} \mathrm{Si}_{2} \mathrm{C}_{5}$ has also been identified as a possible candidate ${ }^{7}$ but its stability is doubtful and the compound has therefore not been included in the phase diagram. Keep in mind that if $\mathrm{Al}_{4} \mathrm{Si}_{2} \mathrm{C}_{5}$ is stable, it will most likely be formed from a supersaturated solution of $\mathrm{Al}$ in $\mathrm{SiC}$ at thermodynamic equilibrium. Furthermore, the formation of $\mathrm{Al}_{4} \mathrm{C}_{3}$ during high dose $\left(3 \times 10^{17} \mathrm{~cm}^{-2}\right.$ and $\left.350 \mathrm{keV}\right) \mathrm{Al}$ implantation at $500^{\circ} \mathrm{C}$ has also been reported. ${ }^{8}$ If $\mathrm{Al}$ is introduced by ion implantation, the silicon to carbon ratio in $\mathrm{SiC}$ is conserved, this is not the case when the $\mathrm{Al}$ atoms are introduced during growth. Hence, different areas have to be considered in the phase diagram for ion implanted $\mathrm{SiC}$ and epitaxially grown material.

A hexagonal lattice can describe $\mathrm{Al}_{4} \mathrm{C}_{3}, \mathrm{Al}_{4} \mathrm{SiC}_{4}$, $\mathrm{Al}_{4} \mathrm{Si}_{2} \mathrm{C}_{5}$, as well as $4 \mathrm{H}-\mathrm{SiC}$ and their space groups have been identified as $R \overline{3} m, P 6_{3} m c, R \overline{3} m$ and $P 6_{3} m c$, respectively. ${ }^{7}$ According to the space groups there is a distinct possibility of aligning the $c$ axis of all the aluminum containing carbides with the $4 \mathrm{H}-\mathrm{SiC}$ lattice in a phase mixture. The extension in the $c$ direction of two unit cells of $\mathrm{Al}_{4} \mathrm{C}_{3}(25 \AA)$ coincides with five unit cells of $4 \mathrm{H}-\mathrm{SiC}(10$ $\AA)$. One unit cell of $\mathrm{Al}_{4} \mathrm{SiC}_{4}(22 \AA)$ and $\mathrm{Al}_{4} \mathrm{Si}_{2} \mathrm{C}_{5}(40 \AA)$ coincides with two and four unit cells of $4 \mathrm{H}-\mathrm{SiC}$, respectively. The mismatch to $4 \mathrm{H}-\mathrm{SiC}$ is negligible for $\mathrm{Al}_{4} \mathrm{C}_{3}$ and $\mathrm{Al}_{4} \mathrm{Si}_{2} \mathrm{C}_{5}$ while a small mismatch is revealed for $\mathrm{Al}_{4} \mathrm{SiC}_{4}$ but not large enough to prevent epitaxial growth. Furthermore, the unit cells of $\mathrm{Al}_{4} \mathrm{SiC}_{4}$ and $\mathrm{Al}_{4} \mathrm{Si}_{2} \mathrm{C}_{5}$ contain "layers" of $\mathrm{Si}-\mathrm{C}$ with the same structure as in $4 \mathrm{H}-\mathrm{SiC}$ and appear as a natural cross over between $\mathrm{SiC}$ and an aluminum containing phase.

In conclusion, we have extracted a solubility limit of 2 $\times 10^{20} \mathrm{~cm}^{-3}\left(1900^{\circ} \mathrm{C}\right)$ with a $30 \%$ increase from $1700^{\circ} \mathrm{C}$ to $2000{ }^{\circ} \mathrm{C}$ for $\mathrm{Al}$ in $4 \mathrm{H}-\mathrm{SiC}$. Heat treatment at $1700^{\circ} \mathrm{C}$ to $2000^{\circ} \mathrm{C}$ of supersaturated $\mathrm{Al}$ doped $4 \mathrm{H}-\mathrm{SiC}$ results in an inhomogeneous $\mathrm{Al}$ distribution due to $\mathrm{Al}$ containing precipitate formation. The precipitates have the preferential orientation of the $c$ axis in $\mathrm{SiC}$. According to the ternary $\mathrm{Al}-\mathrm{Si}-\mathrm{C}$ phase diagram and the lattice structures a probable composition of the precipitating phase is $\mathrm{Al}_{4} \mathrm{SiC}_{4}$ or $\mathrm{Al}_{4} \mathrm{Si}_{2} \mathrm{C}_{5}$ although $\mathrm{Al}_{4} C_{3}$ annot be fully excluded from the HRTEM data.

The authors are grateful to Professor Rositza Yakimova (Linköping University, Sweden) for her aid in heat treatments of samples. Financial support was partly received from the Swedish Foundation for Strategic Research (SSF) SiCEP program.

${ }^{1}$ D. J. Larkin, P. G. Neudeck, J. A. Powell, and L. G. Matus, Appl. Phys. Lett. 65, 1659 (1994).

${ }^{2}$ Y. A. Vodakov, E. N. Mokhov, M. G. Ramm, and A. D. Roenkov, Amorphous and Crystalline Silicon Carbide III, Springer Proc. Phys. Vol. 56, edited by G. L. Harris, M. G. Spencer, and C. Y. Yang (Springer, Berlin, 1992), p. 329.

${ }^{3}$ L. L. Oden and R. A. McCune, Metall. Trans. 18A, 2005 (1987).

${ }^{4}$ J. C. Viala, P. Fortier, and J. Bouix, J. Mater. Sci. 25, 1842 (1990).

${ }^{5}$ J. C. Viala, F. Bosselet, V. Laurent, and Y. Lepetitcorps, J. Mater. Sci. 28, 5301 (1993).

${ }^{6}$ J. Gröbner, H. L. Lukas, and F. Aldinger, CALPHAD: Comput. Coupling Phase Diagrams Thermochem. 20, 247 (1996).

${ }^{7}$ Z. Inou, Y. Inomata, H. Tanaka, and H. Kawabata, J. Mater. Sci. 15, 567 (1980).

${ }^{8}$ J. Stoemenos, B. Pécz, and V. Heera, Appl. Phys. Lett. 74, 2602 (1999). o AIP license or copyright, see http://apl.aip.org/apl/copyright.jsp 